http://journal.uinsgd.ac.id/index.php/biodjati

\title{
MOLECULAR IDENTIFICATION OF BACILLUS DERIVED FROM THE COMMON CARP INTESTINE AND THEIR ANTIBIOTICS RESISTANCE
}

\section{Yuniar Mulyani'*, Karimah Syakirotin², Kiki Haetami³ ${ }^{3}$ Yeni Mulyani ${ }^{4}$, Evi Liviawaty ${ }^{5}$, Mochamad Untung Kurnia Agung ${ }^{6}$}

Selected paper from the $4^{\text {th }}$ Seminar Nasional Biologi (SEMABIO), Bandung-Indonesia, May 18, 2019 (conference.bio.uinsgd.ac.id). Received : July 10, 2019

Accepted : October 29, 2020

DOI: 10.15575/biodjati.v5i2.5263

1,2,3,4,5,6 Faculty of Fisheries and Marine Science, Universitas Padjadjaran, Jl. Raya Bandung-Sumedang KM.21, Jatinangor 45363, Indonesia, Tel. +62-022-87701519, Fax. +62-02287701518

e-mail:

*lyuniarmulyani@gmail.com

̌syakirotin@yahoo.com

33iki.haetami@unpad.ac.id

4yeni.chem@gmail.com

sevi.liviawaty@unpad.ac.id

6mochamad.untung@unpad.ac.id

*Corresponding author

\begin{abstract}
The use of bacteria as a biological control agent in aquaculture is such new hope overcoming the negative impacts of the impropriate use of antibiotics. Bacillus is widely known as a potential probiotic for aquaculture, especially which are derived from aquatic biota. Due to a concern that the role of Bacillus as a probiotic agent will be disrupted by residues of antibiotics in the water, this research aimed to identify Bacillus species from common carp intestine based on the molecular method and investigate their resistance to some commercial antibiotics that widely used in aquaculture. Chloramphenicol, ampicillin, and metronidazole were used to determine the Bacillus resistance to antibiotics using the Kirby Bauer method. The resistance assay was carried out with a bacterial density of $10^{8} \mathrm{CFU} / \mathrm{mL}$. The results showed that Bacillus isolates derived from common carp intestine were closely related and resistant to antibiotics. Isolates that resistant to the three types of antibiotics were Cc.1.9 (CgN9) and Cc.2.18 (CgM18).
\end{abstract}

Keywords: antibiotic resistance, Bacillus, common carp, molecular identification

\section{Citation}

Mulyani, Y., Syakirotin, K., Haetami, K., Mulyani, Y., Liviawaty, E. \& Agung, M. U. K. (2020). Molecular Identification of Bacillus Derived from the Common Carp Intestine and Their Antibiotics Resistance. Jurnal Biodjati, 5(2), 294-302.

\section{INTRODUCTION}

Common carp (Cyprinus carpio L.) is one of the cultured freshwater fish species that popular in Indonesia, especially in West Java. The common carp farming activities are carried out very intensively to meet high consumer demand, and therefore, increase the potential or risk of spreading fish diseases. The spread of fish diseases has been anticipated using biosecurity practice, probiotics, vaccination, and administration of drugs containing chemicals. The presence of antibiotics as one of the efforts to overcome diseases has many negative impacts, such as causing microbial resistance and producing residues that are harmful to humans who consume them (Balcazar et al., 2006). The use of probiotics is an alternative to overcome this problem. Bacteria is well known used as biological control 


\section{JURNAL BIDDJATI}

http://journal.uinsgd.ac.id/index.php/biodjati

agents in many fields, including aquaculture (Verschuere, 2002).

The use of probiotics as an immunostimulant for fish against diseases is an effective effort as well as safe for humans and the environment (Sukenda, 2008). Immunostimulant agents derived from fish are more beneficial because these bacterial groups have been proven to colonize and adapt to their host environment. These include a member of the genus Bacillus. Murilio \& Villamil (2011) noted that Bacillus species is suitable as a probiotic for aquaculture because they are commonly found as microbiota in the aquatic environment and the animal digestive tract. Bacillus species are also widely applied to produce compound used in bacterial pathogenic control (Sorokulova et al., 2007).

However, there is concern that the effectiveness of Bacillus as a probiotic agent in the aquaculture could be impaired by the presence of antibiotics exposure to the aquatic environment due to improper use by farmers. Our previous study has successfully isolated some Bacillus derived from the common carp intestinal (Mulyani, 2018) and this present study aimed to investigate their resistance due to some commercial antibiotics that widely used in aquaculture.

\section{MATERIALS AND METHODS}

According to our previous study, sampling of fish was carried out using the purposive sampling method. Three adult sizes of common carps were collected from the floating net cage at the Cirata reservoir, West Java, Indonesia. The intestinal bacteria were isolated on Nutrient Agar (NA) and MRS Agar medium at $37^{\circ} \mathrm{C}$ incubation. The isolates purification was carried out using the streak plate method. The pure isolates of intestinal bacteria obtained then be characterized using mo- lecular approach. The bacterial genome was extracted using the Boiling method. The 16S rRNA encoding gene then amplified through Polymerase Chain Reaction (PCR) method using 9F (5'-AGA GTT TGA TCM TGG CTG AG-3) and 1492R (5'-GGT TAC CTT GTT ACG ACT T-3') universal primer pair. All PCR cocktails contained 10 ng DNA template and $7.5 \mathrm{pmol}$ of each primer using $2 \mathrm{G}$ Robust Ready Mix (KAPA). Amplification was performed using Eppendorf Mastercycler DNA Engine Thermal Cycler and under the following temperature profile: five minutes in $95{ }^{\circ} \mathrm{C}$ for one cycle and then 45 seconds in $95^{\circ} \mathrm{C}$, one min in $55^{\circ} \mathrm{C}$, one min in $72^{\circ} \mathrm{C}$ for 30 cycles, and a final extension, five minutes in $72^{\circ} \mathrm{C}$ was carried out for one cycle. The PCR products were visualized by electrophoresis in $1 \%$ agarose gel $(80 \mathrm{~V}, 45 \mathrm{~min})$. Agarose gel was stained by GelRed (Biotium) and observed under UV transilluminator (Fisher Scientific $($ ). The $16 \mathrm{~S}$ rRNA gene product was purified, and proceed to the sequencing stage (Macrogen, Korea). Sequencing results were edited using Bioedit software, compared and matched with databases using BLAST on EzTaxon (www.EzBioCloud.net) to determine the type of isolate from the existing database. Phylogenetic analysis was conducted using MEGA7 software. Trees were constructed using Neighbor-Joining (NJ) methods. NJ tree were assessed with 1000 bootstrap replicates (Mulyani, 2018).

The Bacillus isolates resistance was tested by the Kirby Bauer Method (Reynolds, 2011) against ampicillin, metronidazole, and chloramphenicol. These antibiotics have used a concentration of $50 \mathrm{ppm}(\mathrm{w} / \mathrm{v})$ and $100 \mathrm{ppm}$ $(\mathrm{w} / \mathrm{v})$. The resistance test was carried out aseptically by inserting one loop of the bacterial colony into physiological $\mathrm{NaCl}(0,85 \%)$. Then the $100 \mu \mathrm{L}$ bacterial suspension was added to the NA Medium in a petri dish and 


\section{JURNAL BIDDJATI}

http://journal.uinsgd.ac.id/index.php/biodjati

flattened using L-glass. Then antibiotic disc paper was placed on the medium, then incubated at $30^{\circ} \mathrm{C}$ for 24 hours. The inhibitory zone was measured using a caliper with repeated measurements three times, which then the results were compared with the standard antibiotic sensitivity, according to CLSI (Clinical and Laboratory Standards Institute).

\section{RESULTS AND DISCUSSION}

A total of eight single isolates of Bacillus were successfully obtained from the common carp intestines (Mulyani, 2018), as presented in Table 1.

Table 1. Isolates Identification based on EzTaxon (EzBioCloud)

\begin{tabular}{clllc}
\hline No. & \multicolumn{1}{c}{ Isolat } & \multicolumn{1}{c}{ Top-hit taxon } & \multicolumn{1}{c}{ Top-hit strain } & \multicolumn{1}{c}{ Similarity (\%) } \\
\hline 1 & Cc.1.2(CgN2) & Bacillus flexus & NBRC 15715(T) & 95.8 \\
2 & Cc.1.3 (CgN3) & Bacillus flexus & NBRC 15715(T) & 95.5 \\
3 & Cc.1.4(CgN4) & Bacillus cereus & ATCC 14579(T) & 95.59 \\
4 & Cc.1.9(CgN9) & Bacillus carboniphilus & JCM 9731(T) & 68.48 \\
5 & Cc.2.8(CgM8) & CP013984_s Bacillus sp. & DE111 & 99.54 \\
6 & Cc.2.18(CgM18) & Bacillus zhangzhouensis & DW5-4(T) & 100 \\
7 & Cc.2.22(CgM22) & CP013984_s Bacillus sp. & DE111 & 98.57 \\
8 & Cc.2.38(CgM38) & CP013984_s Bacillus sp. & DE111 & 99.56 \\
\hline
\end{tabular}

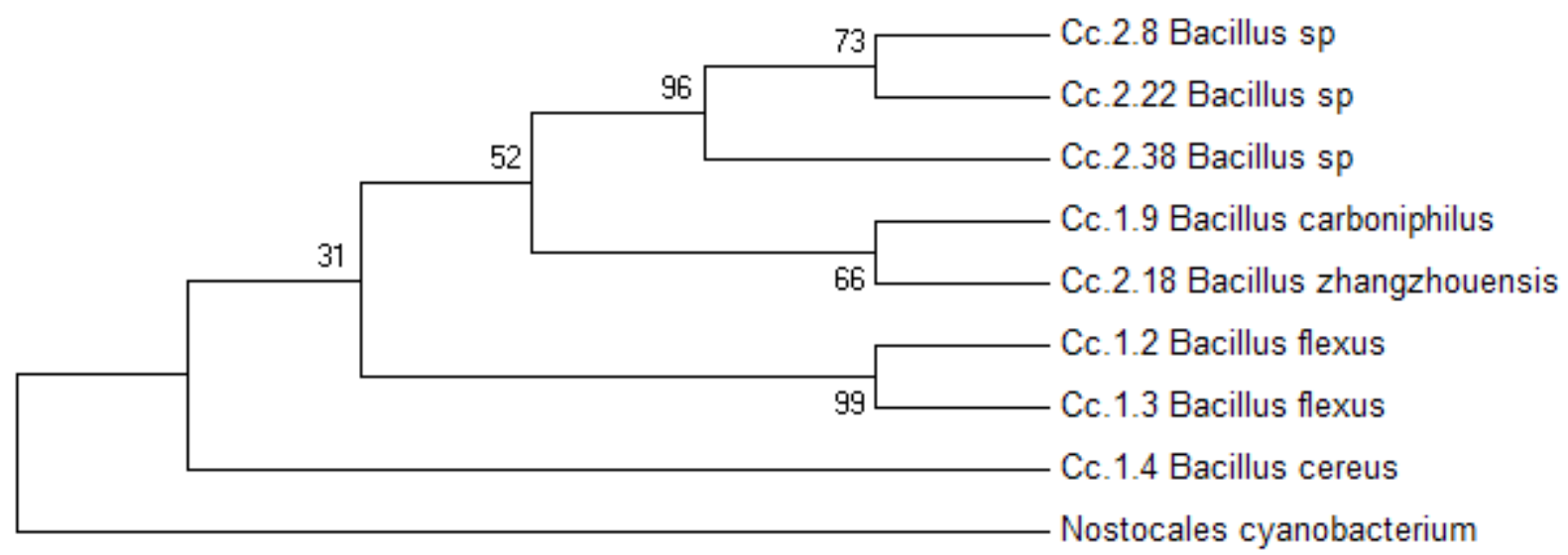

Figure 1. Relationship between Bacillus bacterial isolates from Common carp intestines based on 16 rRNA gene sequences with MEGA 7

According to the phylogenetic tree, showed that all genus are closely related to each other, and Nostocales cyanobacterium was chosen as an outgroup (Figure 1). Cyanobacterium clearly has a kinship far from Bacillus.

Phylogenetics is one of the most frequently used methods in systematics to understand the diversity of living things through the reconstruction of phylogenetic relationships. Jurnal Biodjati 5(2):294-302, November 2020
The phylogenetic tree construction consisted of Nostocales cyanobacterium species and Bacillus bacteria. According to Saitou \& Nei (1987), the neighbor-joining method in the construction of phylogenetic trees is considered to be an efficient method for obtaining the right tree topology. Phylogenetic analysis was performed using a 1000x bootstrap to test the validity of the arrangement of branches in the phylogenetic tree. The bootstrap value 


\section{JURNAL BIDDJATI}

http://journal.uinsgd.ac.id/index.php/biodjati

is shown in figures located on the branches of phylogenetic trees (Dharmayanti, 2011). The value of 73 in the branching built in the Cc.2.8 (CgM8) and Cc.2.22 (CgM22) isolates showed that the validity of the branching construction was $73 \%$. This means that after repetition (bootstrapping) as much as 1000x, 730x same branching obtained. While the validity of branching construction between samples Cc.1.2 (CgN2) and Cc.1.3 (CgN3) was 99\%.

Phylogenetic analysis (Figure 1), shows the kinship between Bacillus bacteria isolated from the fish intestine which consists of one cluster and three subclusters. Clustering is a method that divides a set of data into a similar set of subclasses and has meaning in a phylogenetic tree construction (Mahaputro et al., 2012, Adolfsson et al., 2018). Through the help of clustering analysis, genetic relationships between samples can be more easily understood. The results of the phenogram analysis of eight Bacillus bacterial genomic DNA isolates showed that the bacteria were divided into one main cluster separating from Nostocales sp. as the group. The cluster was divided into three subclusters, where Cc.2.8 (CgM8), Cc.2.22 (CgM22), and Cc.2.38 (CgM38) were joined in subcluster I. Cc.1.9 (CgN9) and Cc.2.18 (CgM18) in subcluster II. Cc.1.2 (CgN2) and Cc.1.3 (CgN3) in the same subcluster, the subcluster III. Whereas Cc.1.4 (CgN4) which not included in the three subcluster showed that Cc.1.4 (CgN4) genetic kinship with the other seven test samples quite far.

According to our previous study, most of Bacillus isolates being used in this research are categorized as non-pathogenic. The performance of fishes survival rate after administrated with Bacillus around $80-100 \%$ (Figure 2) (Mulyani, 2018).

120.00

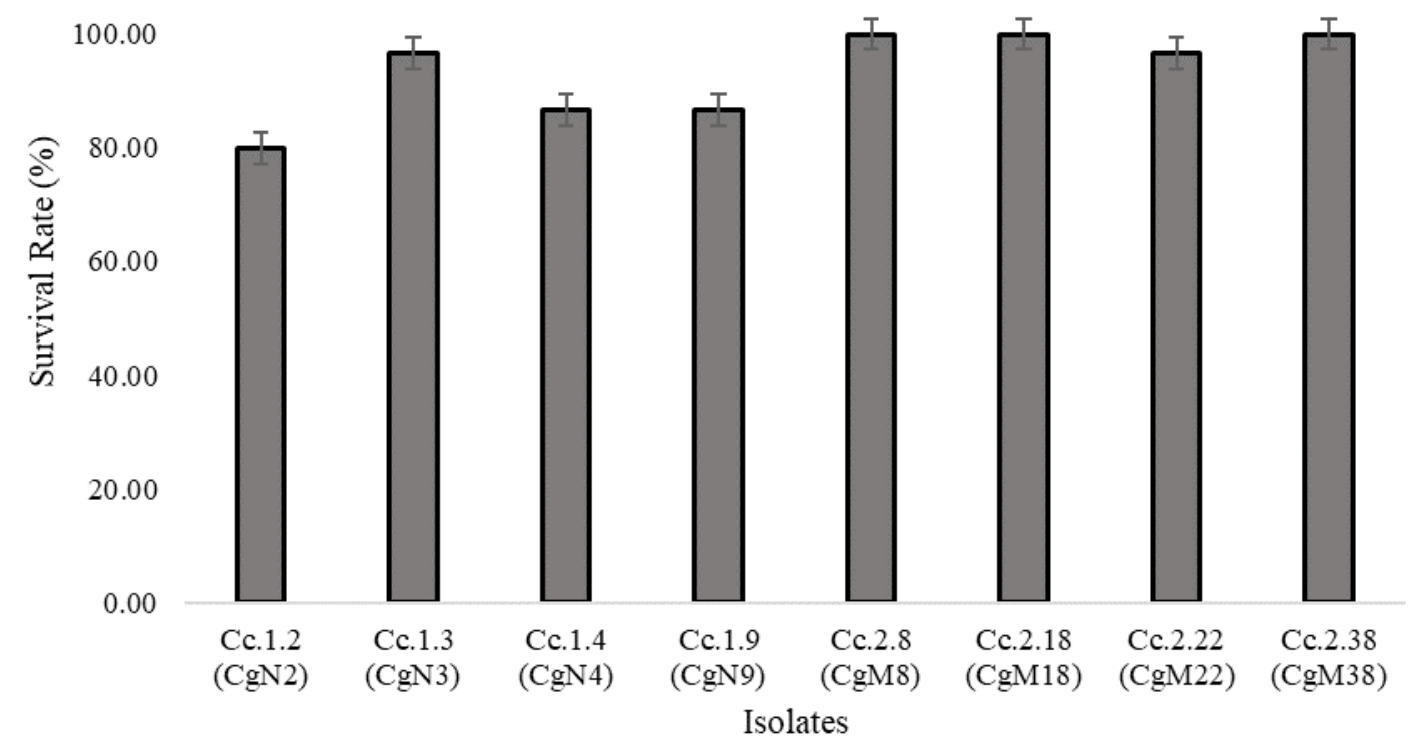

Figure 2. The Survival Rate of Common carp after infected with Bacillus isolates (Mulyani 2018) 


\section{JURNAL BIDDJATI}

http://journal.uinsgd.ac.id/index.php/biodjati

The resistance testing of Bacillus bacteria used three types of antibiotics, namely Chloramphenicol, Ampicillin and Metronidazole. Each type of antibiotic has a different working spectrum. Broadly, the antimicrobial is divided into two types that kill microbes (bactericidal) and that only inhibits microbial growth (bacteriostatic). The benefits of this division are useful in the selection of antibiotics. Based on selective toxicity, chloramphenicol belongs to bacteria that only inhibit the growth of microorganisms (bacteriostatic) and belong to broad-spectrum antibiotics. Meanwhile, ampicillin works by preventing cross-bonding of peptidoglycan at the final stage of the synthesis of cell walls, by inhibiting penicillin-binding protein (Pratiwi, 2008). The spectrum of metronidazole is confined to the obliviate anaerobic bacteria and some microaerophilic bacteria and is most effective against Gram-negative anaerobic bacteria responsible for the inflammation of acute orofacial (Hauser, 2008). Antibiotics are antimicrobial chemical substances produced by various types of microorganisms, especially fungi that have the ability to inhibit growth or kill other microorganisms, wherein this case the intended microorganisms are bacteria. The term antibiotic has also been used extensively in types of synthetic antimicrobials, which are not derived from microorganism products, such as sulfonamides and quinolones.

Observation of clear zones was carried out after incubation for 24 hours. The clear zone around the paper disc shows the sensitivity of bacterial isolates to certain antibiotics. After incubation for 24 hours, the diameter of the inhibitory zone formed from each antibiotic disk was measured using calipers which were then compared to the interpretation standard determined by the Clinical and Laboratory Standard Institute (CLSI 2015).

In general, the mechanism of bacterial resistance to antibiotics includes the mechanism of microorganisms producing enzymes and damaging active drugs, microorganisms changing their permeability to drugs, microorganisms changing the target structure for drugs, microorganisms developing new metabolic pathways avoiding the usual pathways inhibited by drugs, and microorganisms developing enzymes new ones that can still carry out their metabolic functions but are slightly influenced by drugs (Jawetz et al., 2005).

Table 2. Resistance Test Results for Bacillus Bacteria Isolates against Chloramphenicol

\begin{tabular}{lcccc}
\hline \multirow{2}{*}{ Isolates } & \multicolumn{4}{c}{ Chloramphenicol } \\
\cline { 2 - 5 } & $\begin{array}{c}\text { Concentration } \\
50 \mathrm{ppm}(\mathrm{mm})\end{array}$ & $\begin{array}{c}\text { Interpretation } \\
\text { Cc.1.2(CgN2) }\end{array}$ & $\begin{array}{c}\text { Concentration } \\
100 \mathrm{ppm}(\mathrm{mm})\end{array}$ & Interpretation \\
\hline Cc.1.3 (CgN3) & 23.20 & $\mathrm{~S}$ & 28.82 & $\mathrm{~S}$ \\
Cc.1.4 (CgN4) & 10.09 & $\mathrm{~S}$ & 29.21 & $\mathrm{~S}$ \\
Cc.1.9(CgN9) & 0 & $\mathrm{R}$ & 13.74 & $\mathrm{I}$ \\
Cc.2.8 (CgM8) & 14.97 & $\mathrm{R}$ & 0 & $\mathrm{R}$ \\
Cc.2.18 (CgM18) & 4.58 & $\mathrm{I}$ & 24.25 & $\mathrm{~S}$ \\
Cc.2.22 (CgM22) & 14.96 & $\mathrm{R}$ & 5.49 & $\mathrm{R}$ \\
Cc.2.38 (CgM38) & 22.76 & $\mathrm{I}$ & 21.33 & $\mathrm{~S}$ \\
\hline
\end{tabular}

Description: $\mathrm{I}=$ Intermediate; $\mathrm{R}=$ Resistant; $\mathrm{S}=$ Sensitive 


\section{JURNAL BIDDJATI}

http://journal.uinsgd.ac.id/index.php/biodjati

Based on Lewaru et al. (2012), the selection of $50 \mathrm{ppm}$ and $100 \mathrm{ppm}$ chloramphenicol antibiotic concentrations can show the ability of bacterial resistance. In medicine, chloramphenicol is given to patients once a day with different doses (Rismarini et al., 2001), or in other words antibiotics can inhibit bacterial growth for 24 hours depends on the concentration and type of bacteria. The result of the Bacillus bacterial resistance of Chloramphenicol (Table 2) showed that the isolates of Bacillus Cc.2.18 (CgM18), Cc.1.4 (CgN4) and Cc.1.9 (CgN9) in the concentration of 50 ppm were resistant to cholamphenicol, except Cc.2.8 (CgM8), Cc.2.38 (CgM28), Cc.1.2 $(\mathrm{CgN} 2)$ and Cc.1.3 (CgN3) which included in the Sensitive (S) category, and Bacillus Cc.2.8 (CgM8) and Cc.2.22 (CgM22) isolates belong to intermediate (I) category. While Bacillus Cc.1.9 (CgN9) and Cc.2.18 (CgM18) were still resistant to the concentration of 100 $\mathrm{ppm}$. The result showed that the change antibiotic concentration of $100 \mathrm{ppm}$ also causes a change in the clear zone form in all isolates, marked with the increase of the diameter of the clear zone. Proving that bacteria are more difficult to grow on agar media that close to paper discs containing antibiotics.

Based on selective toxicity, chloramphenicol belongs to a bacterium that only inhibits the growth of microorganisms (bacteriostatic) and is classified as broad-spectrum antibiotics. This was evidenced by the large inhibition zone formed in most of the tested Bacillus bacterial isolates. The biggest inhibition zone was formed on Cc.1.3 ( $\mathrm{CgN} 3$ ) isolates at a concentration of $100 \mathrm{ppm}$ with $29.21 \mathrm{~mm}$. According to Pratiwi (2008), broad-spectrum antibiotics can inhibit or kill bacteria from Gram-positive or Gram-negative groups.

The test results showed that Bacillus bacteria were mostly sensitive to chloramphenicol. This antibiotic works by inhibiting protein synthesis that takes place in the ribosome for approximately 24 hours of observation. The peptidyl transferase enzyme will be inhibited by antibiotics. Then the function of the 50S ribosome subunit will be disrupted, which reversibly inhibits protein synthesis by inhibiting the translocation of the tRNA-peptide complex from the location of the amino acid to the peptide location. As a result, the polypeptide chain cannot be extended. Andrews \& Wise (2002) also stated in their study that Bacillus cereus is susceptible to clindamycin, erythromycin, chloramphenicol, vancomycin, aminoglycosides, and tetracycline. The isolates showed a resistance process including isolates of Bacillus Cc.2.18 (CgM18) and Cc.1.4 (CgN4) and concentrations of $50 \mathrm{ppm}$ in the Cc.1.9 (CgN9) isolate (Figure 3). Chloramphenicol resistance is a result of drug destruction by an enzyme controlled by plasmids (Jawetz et al., 2005).

In contrast to the results of the Bacillus bacterial resistance test on ampicillin which showed that all isolates were resistant to Ampicillin at concentrations of $50 \mathrm{ppm}$ and $100 \mathrm{ppm}$ (Table 3). Ampicillin is a penicillin-class antibiotic used to treat grampositive and gram-negative bacterial infections. Penicillin works by influencing the final step of bacterial cell wall synthesis (transpeptidase or crosslinking), so that the membrane is less osmotically stable resulting in Cell lysis. Thus penicillin is called bactericidal (Mycek et al., 2001). 


\section{JURNAL BIDDJATI}

http://journal.uinsgd.ac.id/index.php/biodjati

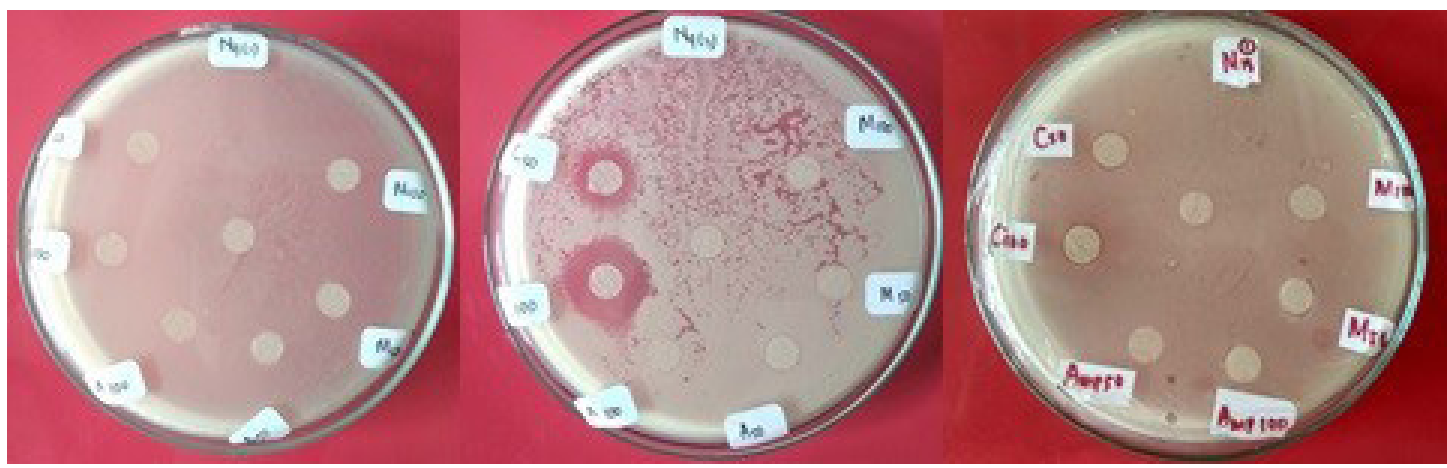

Figure 3. Resistance Test Results of Bacillus Cc.2.18, Cc.1.4 and Cc.1.9 Bacteria. Each sample was tested with three types of antibiotics (Ampicillin, metronidazole and chloramphenicol) on Petri dish, and each antibiotic was given two different treatments (100ppm and 50ppm).

Table 3. Results of the Resilience Test of Bacillus Bacteria Isolates to Ampicillin

\begin{tabular}{|c|c|c|c|c|}
\hline \multirow[b]{2}{*}{ Isolates } & \multicolumn{4}{|c|}{ Ampicillin } \\
\hline & Concentration 50 ppm (mm) & Interpretation & $\begin{array}{c}\text { Concentration } 100 \mathrm{ppm} \\
(\mathrm{mm})\end{array}$ & Interpretation \\
\hline Cc.1.2 (CgN2) & 0 & $\mathrm{R}$ & 0 & $\mathrm{R}$ \\
\hline Cc.1.3 (CgN3) & 0 & $\mathrm{R}$ & 0 & $\mathrm{R}$ \\
\hline Cc.1.4 (CgN4) & 0 & $\mathrm{R}$ & 0 & $\mathrm{R}$ \\
\hline Cc.1.9 (CgN9) & 0 & $\mathrm{R}$ & 0 & $\mathrm{R}$ \\
\hline Cc.2.8 (CgM8) & 0 & $\mathrm{R}$ & 11.96 & $\mathrm{R}$ \\
\hline Cc.2.18 (CgM18) & 0 & $\mathrm{R}$ & 0 & $\mathrm{R}$ \\
\hline Cc.2.22 (CgM22) & 0 & $\mathrm{R}$ & 11.835 & $\mathrm{R}$ \\
\hline Cc.2.38 (CgM38) & 11.72 & $\mathrm{R}$ & 0 & $\mathrm{R}$ \\
\hline
\end{tabular}

Description: $\mathrm{I}=$ Intermediate; $\mathrm{R}=$ Resistant; $\mathrm{S}=$ Sensitive

Ampicillin works by inhibiting the synthesis of microbial cell walls and inhibiting the transpeptidase enzyme causing failure in cell biosynthesis. A further mechanism is to prevent the crosslinking of peptidoglycan in the final stage of cell wall synthesis, which by inhibiting penicillin-binding protein. This protein is an enzyme in the plasma membrane of bacterial cells that normally involved in the addition of amino acids that cross-linked with bacterial cell wall peptidoglycan, and blocks the activity of the transpeptidase enzyme so that the bacterial cell wall becomes fragile and easily lysed (Pratiwi, 2008).
However, the results of tests carried out on Bacillus bacteria obtained from the gut of common carp showed that ampicillin did not work properly. All isolates were declared resistant to this antibiotic. So it can be stated that Bacillus bacteria have a high level of resistance to this type of antibiotic. This can occur because ampicillin is a prototype of the broad spectrum aminopenicillin group, but its activity against Gram-positive is less than penicillin G. All of these group penicillins are damaged by $ß$-lactamase produced by gram-positive bacteria like Bacillus. 


\section{JURNAL BIDDJATI}

http://journal.uinsgd.ac.id/index.php/biodjati

Table 4. Bacillus Bacteria Isolate Resistance Test Results for Metronidazole

\begin{tabular}{lcccc}
\hline & \multicolumn{3}{c}{ Metrodinazole } \\
\cline { 2 - 5 } Isolates & Concentration $50 \mathrm{ppm}(\mathrm{mm})$ & Interpretation & $\begin{array}{c}\text { Concentration } 100 \mathrm{ppm} \\
(\mathrm{mm})\end{array}$ & Interpretation \\
\hline Cc.1.2 (CgN2) & 0 & $\mathrm{R}$ & 0 & $\mathrm{R}$ \\
Cc.1.3 (CgN3) & 0 & $\mathrm{R}$ & 0 & $\mathrm{R}$ \\
Cc.1.4 (CgN4) & 0 & $\mathrm{R}$ & 0 & $\mathrm{R}$ \\
Cc.1.9(CgN9) & 0 & $\mathrm{R}$ & 0 & $\mathrm{R}$ \\
Cc.2.8 (CgM8) & 0 & $\mathrm{R}$ & 16.09 & $\mathrm{I}$ \\
Cc.2.18 (CgM18) & 0 & $\mathrm{R}$ & 0 & $\mathrm{R}$ \\
Cc.2.22 (CgM22) & 0 & $\mathrm{R}$ & 0 & $\mathrm{R}$ \\
Cc.2.38 (CgM38) & 7.68 & $\mathrm{R}$ & 6.91 & $\mathrm{R}$ \\
\hline
\end{tabular}

Description: $\mathrm{I}=$ Intermediate; $\mathrm{R}=$ Resistant; $\mathrm{S}=$ Sensitive

Whereas the results of the resistance test of Bacillus bacteria to Metrodinazole showed that all isolates at the Metronidazole concentration of $50 \mathrm{ppm}$ and $100 \mathrm{ppm}$ were resistant except the Cc. 2.8 isolates that belong to the intermediate category (Table 4). Metronidazole is known as an antibacterial, antiprotozoal and radiation-sensitizer. The mechanism of action is to inhibit nucleic acid synthesis by damaging DNA. As an antiprotozoal, metronidazole works by destroying the protozoa. As for radiation-sensitizers, metronidazole is effective in damaging unwanted cells. This medicine is also effective against anaerobic bacteria that work by disrupting bacterial DNA so that it inhibits nucleic acid synthesis. The metronidazole spectrum is limited to obligate anaerobic bacteria and some microaerophilic bacteria and is most effective against gram-negative anaerobic bacteria which are responsible for acute orofacial inflammation and chronic periodontitis. Bacillus itself is known to be a gram-positive aerobic bacterium. This is thought to be the cause of the resistance of Bacillus bacteria to the antibiotic metronidazole.

As a resume, it was found in this study that Bacillus isolates derived from common carp intestine were resistantto antibiotics. This can indicate that Bacillus may still be able to survive to carry out its duties as a biological control agent (probiotic) in aquatic environments contaminated with antibiotic residues. Isolates that are resistant to the three types of antibiotics were Cc.1.9 (CgN9) and Cc.2.18 (CgM18).

\section{ACKNOWLEDGEMENTS}

This research is financially support by the University of Padjadjaran through UNPAD Fundamental Research Grants (RFU) year of 2018, 2798/UN6.M/LT/2018.

\section{REFERENCES}

Adolfsson, A., Ackerman, M. \& Brownstein, N. C. (2018). To Cluster, or Not to Cluster: An Analysis of Clusterability Methods. Pattern Recognition, 88, 13-26.

Balcazar, J. L., de Blas, I., Ruiz, Z. I., Cunningham, D., Vendrell, D. \& Muzquiz , J. L. (2006). The Role of Probiotics in Aquaculture. Veterinary Microbiology, 114(3-4), 173-186.

Jawetz, E., Melnick, J. L. \& Adelberg, E. A. 


\section{JURNAL BIDDJATI}

http://journal.uinsgd.ac.id/index.php/biodjati

(2005). Medical Microbiology, XXII Edition. Jakarta: Salemba Medika Publishers.

Lewaru, S., Riyantini I. \& Mulyani Y. (2012). Identifikasi Bakteri Indigenous Pereduksi Logam Berat Cr (VI) dengan Metode Molekuler di Sungai Cikijing Rancaekek, Jawa Barat. Jurnal Perikanan dan Kelautan, 3(4) :81-92.

Mahaputro, G., Mishra, D., Shaw, K., Misha, S. \& Jena, T. (2012). Phylogenetic Tree Construction of DNA Sequences using Clustering Methods. Procedia Engineering, 38.

Mulyani, Y., Aryantha, I. N. P., Suhandono, S. \& Pancoro, A. (2018). Intestinal Bacteria of Common Carp (Cyprinus carpio L) as Biological Control Agent for Aeromonas. Journal of Pure and Applied Microbiology, 12(2), 601-610.

Murilio, I \& Villamil, L. (2011). Bacillus cereus and Bacillus subtilis used as probiotics in rotifer Branchionus plicatilis cultures. Journal of Aquaculture Research and Development, 7, 1-5.

Mycek, M. J, Harvey, R. A. \& Champe, P. C. (2001). Pharmacology Picture Review 2nd ed. H. Hartanto, ed. Jakarta: Widya Medika.

Pratiwi, S. T. (2008). Mikrobiologi Farmasi. Jakarta: Erlangga.

Reynolds, J. (2011). Kirby-Bauer Procedure. Dallas (USA): Richland College.

Rismarini, Anwar, Z. \& Merdjani, A. (2001). Perbandingan Efektifitas Klinis antara Kloramfenikol dan Tiamfenikol dalam Pengobatan Demam Tifoid pada Anak. Sari Pediatri, 3(2): 83-87
Saitou, N. \& Nei, M. (1987). The Neighbor-Joining Method: A New Method For Constructing phylogenetic Trees. Molecular Biology and Evolution. 4(4), $406-425$.

Singh, A., Rathore, G., Singh, V., Mani, I., Singh, R., Mishra, S., Mishra, B. \& Verma, O. (2009). Bacterial Resistance to Oxytetracycline in Different Life Stages of Indian Freshwater Carp Aquaculture System. International Journal of Microbiology, 1(1), 25-34.

Sukenda, Jamal,L, Wahjuningrum,D. \& Hasan, A. (2008). Penggunaan Kitosan untuk Pencegahan Infeksi Aeromonas hydrophila pada Ikan Lele Dumbo Clarias sp. Jurnal Akuakultur Indonesia, 7(2), 159-169.

Sorokulova, I. B., Pinchuk, I. V., Denayrolles, M., Osipova, I. G., Huang, J. M., Cutting, S. M. \& Urdaci, M. C. (2007). The Safety of Two Bacillus Probiotic Strain for Human Use. Digestive Diseases and Sciences, 53(4), 954-963.

Verschuere, L., Rombaut, G., Surgeloos, P. \& Verstraete, W. (2002). Probiotic Bacteria as Biological Control Agents in Aquaculture. Microbiology and Molecular Biology Reviews, 64(4): 655-671. 